\title{
Promoting Luminor Hotel Pahlawan, Sidoarjo to Its Target Market Using a Marketing Booklet
}

\section{Asti Kusumaningtyas}

English Department, Faculty of Letters, Petra Christian University, Siwalankerto 121-131, Surabaya 60236, Indonesia.

E-mail: asti.kusumaningtyas@gmail.com

\begin{abstract}
This is a creative thesis report on a problem that Luminor Hotel Pahlawan, Sidoarjo has. The three-star hotel located in Sidoarjo is believed to have ineffective marketing tools. Their prospects tend to ask for further information such as pictures and detail description of the facilities. Flyers that the salespeople usually give to the prospects are less informative. Thus, in order to introduce the product to the representatives of the prospects a marketing booklet is needed. Marketing booklet which has more spaces to deliver information can help the salespeople to answer customers' needs. To persuade the readers, Luminor Hotel Pahlawan, Sidoarjo's Unique Strength Points (USP) will be emphasized in the marketing booklet contents.

Keywords: marketing tool, marketing booklet, unique selling point, target market.
\end{abstract}

\section{INTRODUCTION}

I was an intern in Luminor Hotel Pahlawan, Sidoarjo from September 9 until December 2019. Luminor is a hotel, managed by Waringin Hospitality Hotel Group. Waringin Hospitality is considered as a new Hotel Group since it was established in 2010. In the past, Waringin Hospitality only had one Hotel which is Hotel 88 located in Jalan Mangga Besar Raya No. 120, Jakarta Pusat and started operating on July 19, 2010. As time goes by, Waringin Hospitality already manages 16 properties spread in Indonesia. Luminor itself has several branches in Indonesia such as Jakarta, Jambi, Surabaya, Jember, Banyuwangi, and Sidoarjo. Luminor Hotel Pahlawan, Sidoarjo where I did my internship is a three-star Business Hotel located in Sidoarjo. Strategically located in the heart of Sidoarjo, near toll and mall access, Luminor Hotel Pahlawan, Sidoarjo offers the best three-star Hotel for business or leisure accommodation. It is exclusively inspired by the modern and artistic ambience. Since it is a business hotel, most of its customers are from corporations and the government who rent meeting rooms for events such as gathering, meeting, training, and many more. They also rent rooms for their guests.

Comparatively there are more hotels in Surabaya than in Sidoarjo. Before Luminor Hotel Pahlawan, Sidoarjo was established, Sidoarjo only had a few hotels. There were only two three-star hotels in Sidoarjo which are Sun Hotel and Delta Sinar Mayang Hotel. Right now, Luminor Hotel Pahlawan, Sidoarjo has two competitors in Sidoarjo which are Sun Hotel and Fave Hotel Sidoarjo. Moreover, Swiss Belinn Hotel Airport and Premiere Place which are located in Juanda Street are also competitors for Luminor Hotel Pahlawan, Sidoarjo.

Luminor Hotel Pahlawan, Sidoarjo provides five types of rooms which are deluxe, executive, executive family, junior suite and suite room. All of those rooms are equipped with full amenities, guest supplies, coffee and tea maker. The difference is in the size of the room. Also, Suite and Junior Suite are equipped with a sofa and mini-pantry. Besides providing rooms, Luminor hotel also has its own restaurant within the hotel. It is called "Wajik Resto". It serves more than 100 kinds of food every day and opens 24 hours. It also has special packages such as Lunch and Munch Buffet, Rendezvouz Dinner Buffet, and Sunday Family Lunch Buffet. Luminor Hotel Pahlawan, Sidoarjo also provides 5 types of multifunction rooms which 
Kusumaningtyas: Promoting Luminor Hotel Pahlawan, Sidoarjo to Its Target Market Using a Marketing Booklet

are Smart, Energyc, Dynamic, Mezanine, and Ballroom. For the meeting room itself, Luminor does not rent it. They sell meeting packages which are coffee break, lunch, or dinner for meeting, therefore for those who bought the meeting package (coffee break, lunch, or dinner) can use the meeting room based on the capacity.

Within three months of internship at Luminor Hotel Pahlawan, Sidoarjo, I found the main problem which is faced by Luminor Hotel Pahlawan, Sidoarjo and became my concern. The problem is he ineffective way to promote Luminor Hotel Pahlawan, Sidoarjo to its target market. I found out this problem through observation. During my three-month internship at Luminor Hotel Pahlawan, Sidoarjo I was assigned to do telemarketing. In total there were five people doing sales visits and three people doing telemarketing. For a three-star business hotel, mostly three people doing sales visit and two people doing telemarketing are more than enough. In this case, Luminor Hotel Pahlawan, Sidoarjo tried to increase their number of prospects by increasing the resources in the sales department. However, it failed. Even though the resources to do telemarketing and sales visit increased, the visitors who came to Luminor Hotel Pahlawan, Sidoarjo to buy its products and service still did not reach the target. It can be seen firstly from the sold banquet revenue which still does not meet the expectation from the head office. For instance, in November the budget of the banquet (meeting rooms revenue) does not reach the projected income that has been set. Secondly, the projected income is Rp. 750,358,068 meanwhile the realization was only Rp. 386,812,815. Lastly, the occupancy rates from September to November due to sold rooms is only $72.5 \%$. Due to the fact that soon Luminor Hotel Pahlawan, Sidoarjo will have more competitors in Sidoarjo, the occupancy should be higher. Lastly, the special buffet package at Luminor Hotel Pahlawan, Sidoarjo is still known by few people.

As a telemarketer, the struggle that I faced when doing telemarketing was that some prospects asked about further information. The marketing tool that the marketing team sent after telemarketing was only a price list which is considered as boring, not appealing, and less informative. Prospects also skipped the email immediately because the first thing which appeared was the list of expensive prices. It gave them the impression that Luminor Hotel Pahlawan, Sidoarjo is an expensive business hotel without knowing what products or services that they can get. Moreover, some prospects who did not not know about Luminor Hotel Pahlawan, Sidoarjo were wondering what kind of hotel Luminor Hotel Pahlawan, Sidoarjo is. Sending a price list is ineffective to follow up the prospects since the prospects do not have insight into whether the hotel's products and services can fulfill their needs or not. They would like to see what kind of facilities that Luminor Hotel Sidoarjo has and also they want to see the pictures. However, when we followed up the prospects via email, all that we sent was just the price list because they do not have any marketing booklet. As a result, some prospects did not have the visualization about the product that we offered. They do not get the intention to buy the products because they were not interested.

Furthermore, when the sales people did a sales visit, the only things they brought were the price list and brochure of the buffet package in Wajik Resto \& Café. When the sales did a sales visit, it means that they present the products and services of Luminor Hotel Pahlawan, Sidoarjo to prospective customers who are usually the representative of a company. However, the sales people of Luminor Hotel Pahlawan, Sidoarjo did not have any tools to present the product. They just presented it verbally without any visualization. This promotion can be considered as unprofessional. Since Luminor Hotel Pahlawan, Sidoarjo claims itself as the best business hotel in the center city of Sidoarjo, therefore, they need to show professionalism to their target market when they are doing sales visits.

Due to the problem, I decided to choose an effective way to introduce and promote the company's products by the marketing team as my creative thesis project. Due to this problem, I 
will make a marketing booklet focusing on Luminor Hotel Pahlawan, Sidoarjo products and offers. This tool can be used in helping the sales team to introduce as well as promote a company's product while still giving a product presentation to the targeted corporation or government. This tool can also be used by the customers, especially the representatives of government and companies when they intend to stay or have events in Luminor Hotel Pahlawan, Sidoarjo nect time. It can be used to refresh their memory about Luminor Hotel Pahlawan, Sidoarjo products even after the product presentation. This tool can also be sent directly to the targeted corporate without having to make an appointment beforehand or when the sales do telemarketing.

There are several considerations I use a marketing booklet instead of promotional video. First of all is that by using Marketing Booklet, people can know about Luminor Hotel Pahlawan, Sidoarjo's product and services better because the description will be clearer. Since it is more informative, it is expected that customers will have more intense desire to buy Luminor Hotel Pahlawan, Sidoarjo's products and services. This tool consists of enough information about the Hotel as well as the Hotel's main products packed in an attractive and interesting design. Secondly, printed media is easier to read by prospective customers who are mostly 40 years older. People who are in that age usually prefer printed media because it is more practical.

Thirdly, marketing booklet is easier to be distributed. Promotional videos are not as flexible as marketing booklets. Since the sales team never brought laptops when they do sales visits, it will be difficult to present the product with a form of video. The sales people might present the video on their smartphone, but it seems unprofessional. From the reasons above, therefore I choose marketing booklet as the effective promotional tool to introducing and promoting Luminor Hotel Sidoarjo - Pahlawan's products and services.

\section{Literature Review}

\section{Hotel}

Hotel is one of the scopes in hospitality business. It offers room services such as laundry, and products such as food and beverages. Hotels play an important role in providing facilities for the transaction of business, for meetings and conferences, for recreation and entertainment. Walker (2013, p.8) defines nowadays hotel business is usually franchised. There are some hotels in Surabaya which are franchised, they are JW Marriott, Sheraton Four Points, Wyndham Hotels, and many more. Luminor Hotel Sidoarjo - Pahlwan itself is not a franchise hotel. It is one of the branches of Waringin Hospitality Hotel Group. The organization system affects the operational system in the hotel. Usually, the system in the hotels which are not franchised is more centered. Some big decision making based on the head office or the hotel group.

Furthermore, whatever the criteria used in hotel guides and in classification and grading system in existence in many countries, normally at least four or five classes or grades have been found necessary to distinguish adequately in the standards of hotels and these have found some currency among hotel users. This classification is what we know as hotel rates. Usually, there are five rates which are five-star, four-star, three-star, two-star, and one-star hotel. The extremes of luxury and basic standards, sometimes denoted by five-star and one-star respectively are not difficult concept. The mid-point (two-star, three-star, and four-star) on any scale denotes the average without any particular claims to merit. The type of a hotel is obviously important to this project because it will determine the customer of the hotel. The customer of five-star hotel is dominated by upper-class, mid-point hotel is dominated by middle class, and one-star hotel is dominated by working class. The concept of the hotel also determines the guests who come to 
Kusumaningtyas: Promoting Luminor Hotel Pahlawan, Sidoarjo to Its Target Market Using a Marketing Booklet

the hotel. For resort hotel the customer mostly are tourists. Meanwhile, for business hotel, the guests are mostly business people from many varieties.

\section{Marketing}

These following theories discuss about how marketing works in business. It is important to know how marketing works in order to make the efficient marketing booklet for Luminor Hotel Pahlawan, Sidoarjo's prospects. According to Titley $(2015$, pg. 178) on the book Complete Business Studies for Cambridge IGCSE \& 0 Level, marketing is not just about advertising and selling. To be successful, it must include identifying customers' needs and wants, satisfying consumer needs and wants, and anticipating changes in customer needs and wants. From the theory above, it is concluded that in the process of making a marketing booklet, the business needs to adapt with the customer preferences. To satisfy and grab customers' attention, a marketing booklet must highlight the products or services that becomes customers' intention. Also, highlighting new products or services which are not currently provided by competitors.

\section{Marketing Mix}

Marketing mix refers to the combination of all the activities involved in an organization's marketing strategy for a product. Marketing mix consist of 4Ps which are product, price, place, promotion. The first element is the product. It is about the design, quality and packaging of the products or services. It is also about how the product compares to the rivals. The second one is price. The price at which the product is sold and the strategies used to be competitive in the market. The next element is place. Place here means the channels of distribution to final consumers. The last one is promotion. Promotion is about brand name and product image. Advertising and other promotions are needed to raise consumer awareness.

Among those four points, promotion is the essential thing because it is the action to inform people about the product existence. Promotion is an action of communication that has a purpose to persuade others. The goal is to make the target market accept the idea or concept or thing offered to them. After they accept the idea or concept, the expected action is they will purchase the idea or concept or thing offered.

\section{Promotion}

According to Yeshin (2006, p.7), promotion is "a planned and implemented marketing activity that both product or services appeal and changes customer behavior positively in return for an additional benefit for purchase or participation." Another definition from Weitz \& Wensley (2002, p. 330), promotion can be defined as "an action-oriented marketing event whose purpose is to have direct impact on the behavior of the firm's customers." Due to the description above, promotion can be defined as an activity which is done by a company to make its products or services become more appealing and have direct impact on the customers' behavior to get the customers' interest to make a purchase. According to Chris Hackley (2010, p.9, 30), the types of promotion or marketing tools can be divided into five different tools which are direct mail, internet and not-so new media, sales promotion, trade conference and exhibition, and advertising. Luminor Hotel Pahlawan, Sidoarjo is using direct mail and advertising as its promotion strategies.

\section{Brand and Branding}


Based on an online journal written by Tanya Sammul Bonici (Bonnici, 2015), a brand can be defined as a set of tangible and intangible attributes designed to create aware-ness and identity, and to build the reputation of a product, service, person, place, or organization. Based on the explanation above, brand is the intangible that makes people love, trust and believe the product of company. Brand is not only about logo, tagline, or trademark but, it is more than that which can affect customer's thoughts about that company. It can be concluded that branding is the process to get customer attraction to buy products and to build brand awareness. Branding is the way to promote a company's brand to customers so they can believe and buy the products that company offers. Luminor Hotel Pahlawan, Sidoarjo also does branding such as holding wedding exhibitions, cooperating with the media to promote its products.

\section{USP}

Nowadays, there are a lot of businesses including hospitality business such as hotels that offer the same type of products or services. Therefore, it is important to have unique selling points that differentiate one company to other companies as USP is a summary of a company's unique points that can make a company becomes valuable in the eyes of its customers and lead customers to buy the product or service. According to Owen (Gough, 2017), there are three reasons why having USPs is important for a company.

The first reason why having USP is important is it is a must for a company to be able to present and show customers that a company can offer advantages that other cannot offer to them. Therefore, it will lead to winning over potential customers whether within the country or internationally as its second importance of having USP. The third reason, which also important, is it can help a company communicate a brand's advantage in a clear and persuasive way as well as differentiate a company with its competitors.

\section{SWOT Analysis}

The analysis technique used in this project is SWOT Analysis. SWOT is the abbreviation terms for Strength, Weakness, Opportunity and Threat analysis. This analysis technique is used to learn, start and develop a company based on SWOT factors which gained from internal (Strength and Weakness) and External (Opportunity and Threat) factors. To be more specific, each factor stands for specific needs. Strengths are those factors which give benefits for the company; weaknesses are factors that cause loss; opportunities are external factors which give benefits for the company; and last, threats are external factors that give disadvantages to the company (Materson, Phillips \& Pickton, 2017).

In this project, the SWOT Analysis is applied to the products in order to figure out the unique strength point (USP); it is important to construct the content of the marketing booklet. The following instructions are the steps of doing SWOT Analysis. First, brainstorming all issues that can be classified under the four categories (Strength, Weakness, Opportunity and Threat). In the first stage, it is better to write down issues as much as possible, then sort it out in the next stage. The second step is to cluster similar or related issues together. The third step is to analyze the issues, generalize those issues into broader strengths, weaknesses, opportunities and threats and prioritize them. Lastly, synthesizes the information gathered. Then, identifies the main issues that require changes to be made and makes decisions about how to introduce these changes (Baxter, 1995). In the end, Key for effective SWOT Analysis is realism and honesty. In addition, during the SWOT analysis, it is necessary to be realistic and honest to the object analyzed.

\section{Marketing Booklet}


Kusumaningtyas: Promoting Luminor Hotel Pahlawan, Sidoarjo to Its Target Market Using a Marketing Booklet

According to Oxford Dictionaries, Marketing is "The activity of selling products of a company". Then, I also took the definition of marketing booklet according to Oxford Dictionaries, Booklet is a small thin book with a cover that contains information. From that explanation above, I can conclude that a marketing booklet is a small book size $18.5 \times 21 \mathrm{~cm}$ that provides more information about a company's products or services that helps the sales people when selling the products to the customer. A good marketing booklet should be in the right size. If it is too big the cost of its production will be expensive and it will be hard to be carried by the sales people. But, if it is too small, the pictures may not be that clear and there may be less description that make the information undelivered well.

\section{Target Market}

According to Carolina Rogoll on her book Star Brands: A Brand Manager's Guide to Build, Manage and Market Brands (2015, p.20), target market is a selected distinct customer target that will drive focus on the innovation efforts, marketing efforts, and ultimately will be the source of short and long term business growth.

From the statement above, I can conclude that a hotel cannot be everything for everybody because it is exhausting and almost impossible to do. A brand will not appeal to all consumers in the marketplace. In terms of making promotional tools, it can be very expensive to try to reach everybody. Thus, we should define and select our unique type of customer that we want to attract and delight. Having a unique target in mind will help focus the brand efforts, such as communication and product development where they matter most.

\section{METHOD}

\section{Respondents of the Data Collection}

Based on Luminor's sales and marketing monthly report, there are 195 institutions and individuals which use Luminor Hotel Pahlawan, Sidoarjo's products and services within three months (November - Desember 2019). Due to the data, corporation have the biggest percentage which is $51.5 \%$. Next, it is followed by the government with $32.7 \%$. The last one is coming from individual segment which is only $15.8 \%$. Following the percentage above, the questionnaire was fulfilled by 20 people. 10 people are the representative of corporation, 6 people from government, and 4 people from individual segments. Those 20 people are the sample of 195 institutions and individuals who choose Luminor Hotel Pahlawan, Sidoarjo as their choice of accommodation.

\section{Methods of the Data Collection}

There are 3 sections in the questionnaire. The first section is about personal data of the respondent. The first section is important to find out the suitable background of the respondents. Since the survey was only fulfilled by 10 respondents, therefore those 10 respondents supposed to be the most reliable respondent. They have to be the customers who have become Luminor Hotel Pahlawan, Sidoarjo for at least 2 times. On the first section there are several questions about the background of the customer such as institution name, occupancy or position in the institution, residence, age, how long has experienced Luminor Hotel Pahlawan, Sidoarjo products and services.

The second section contains questions about the hotel. This section reveals the customers' perception about the hotel. They are about the facilities in Luminor Hotel Pahlawan, Sidoarjo such as room, meeting room, and Wajik Resto and Café. Respondents can give their 
perception, impression about the facilities. The best facilities are highlighted in the marketing booklet with their good character in their description.

The third section discusses the marketing tool. In this section we would like to know how the customer finds out about Luminor Hotel Pahlawan, Sidoarjo and its facilities. This section will show whether the customer agrees or not with the existence of a marketing booklet as one of the promotion tools that Luminor Hotel Pahlawan, Sidoarjo has.

\section{FINDINGS AND DISCUSSION}

It is important to reveal the customer characteristic because the design of the marketing booklet supposed to adjust the customer characteristic and needs. Based on the age, education level, and income level, the customer of Luminor Hotel Pahlawan, Sidoarjo are people on the range age of late 30 and early 50. Based on the theory of age in sociolinguistics, people on this range of age have tendency to use formal words instead of vernacular. So, the language use in the marketing booklet should be in formal way and informative for the audience.
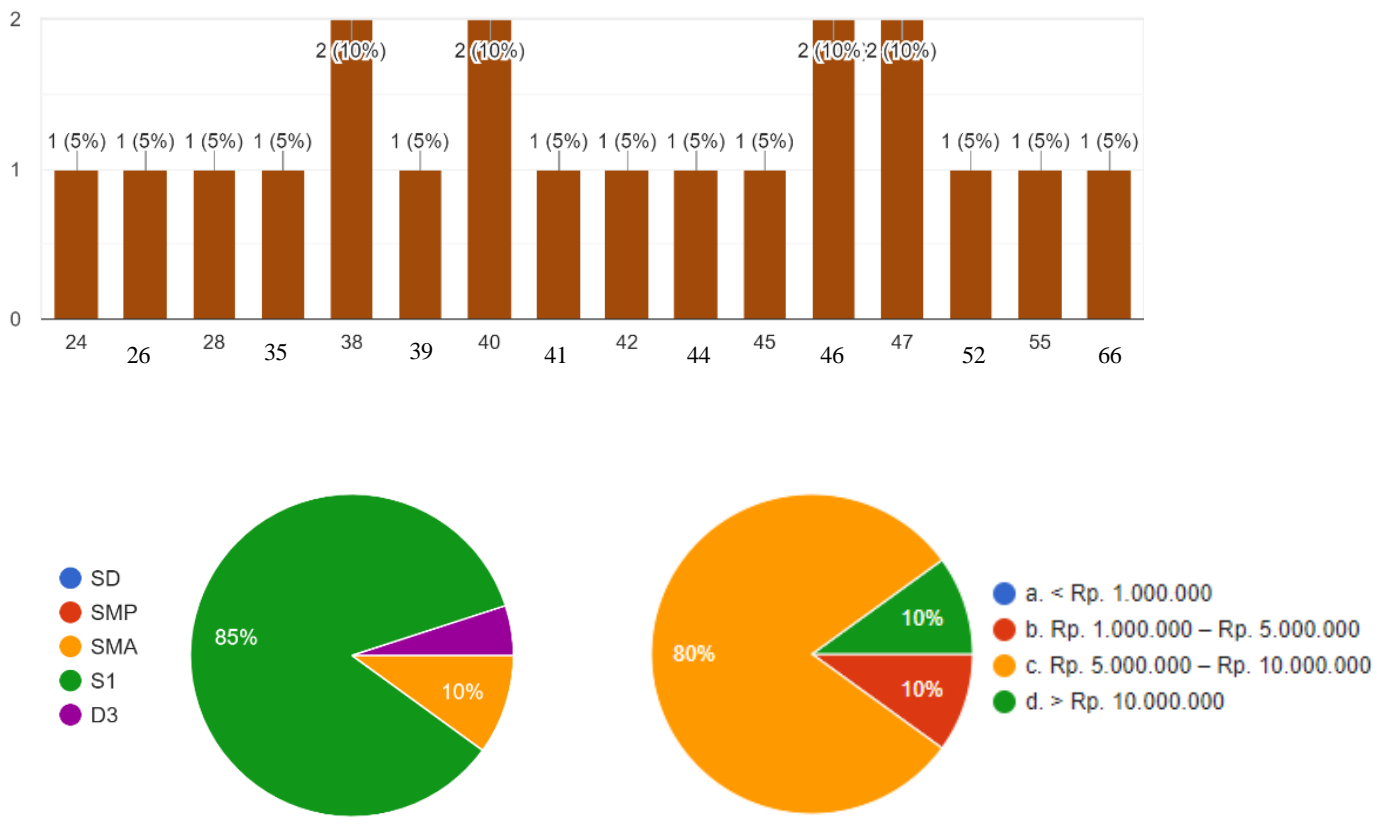

Next, from the education and income level, the customers mostly finished their undergraduate degree and they work with amount salary of salary around Rp. 5,000,000 - Rp. $10,000,000$. From this aspect, they are included as middle-class group, and most likely upperclass group also. As I have mentioned in chapter 2, middle-class to upper class group tended to be more likely to pay attention to the quality of the products and services and also Brand they would use or consume. This is because they had more buying power than lower-class group.

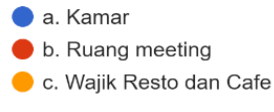

c. Wajik Resto dan Cafe

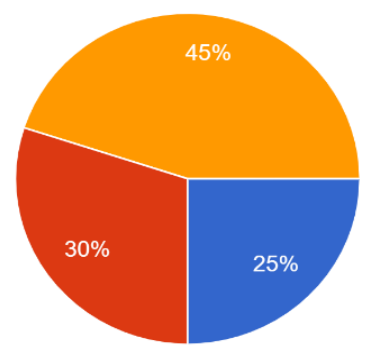

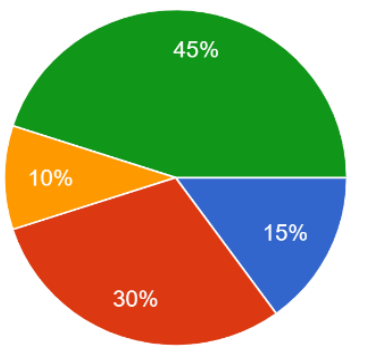

a. Harga

b. Lokasi

c. Fasilitas

d. Brand hotel 
Kusumaningtyas: Promoting Luminor Hotel Pahlawan, Sidoarjo to Its Target Market Using a Marketing Booklet

Therefore, the marketing booklet should emphasize the quality of Luminor Hotel Pahlawan, Sidoarjo so that the audience can feel benefited although they need to pay higher than to other hotels such as FaveHotel Sidoarjo and Sun Hotel Sidoarjo.

In the second section, respondents are asked about their point of view of Luminor Hotel Pahlawan, Sidoarjo to find out the hotel's USP. Luminor Hotel Pahlawan, Sidoarjo provides 3 facilities which are room, meeting room, and restaurant. From those 3 facilities, Wajik Resto and Café are the most favorite for the customers. The reason is because Wajik Resto and Café has buffet package meanwhile other hotels around Luminor Hotel Pahlawan, Sidoarjo does not provide it. According to the respondents, Wajik Resto and Café is also a very comfortable place for social gathering such as arisan, birthday, and many more. However, Wajik Resto and Café are rarely highlighted on the flyer.

From the data above, $45 \%$ of the respondents are choosing Luminor Hotel because of its brand. Evidently, Luminor brand by Waringin Hospitality is considered as high-quality hotel brand even though most of them are 3-star Hotels. Moreover 30\% of the respondent choose to stay at Luminor Hotel Sidoarjo because of its location which is strategic in Sidoarjo. Lastly, from the question 'What are the benefits you feel after experiencing Luminor Hotel Pahlawan, Sidoarjo?' we can find out that Luminor Hotel Pahlawan, Sidoarjo is a hotel with an excellent service from the customers' point of view.
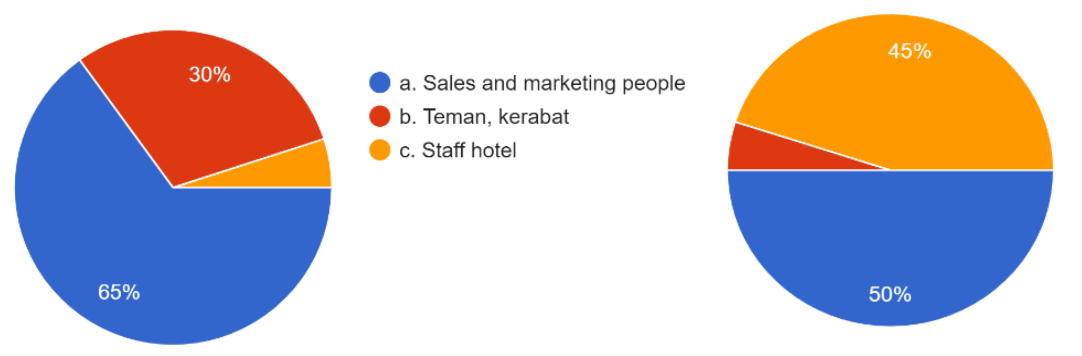

a. Selebaran

b. Website

c. Social media (Instagram, WA blast)

d. Pameran
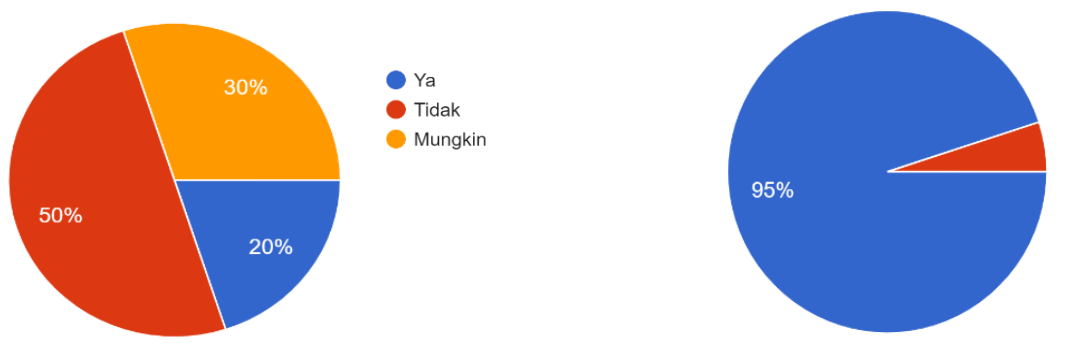

a. Ya

b. Tidak

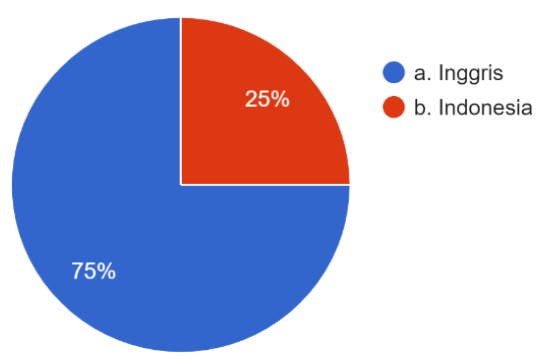

The third section reveals the customers' point of view about Luminor Hotel Pahlawan, Sidoarjo current marketing tool and their opinion about the idea of marketing booklet. Most of the customers knew Luminor Hotel Pahlawan, Sidoarjo mostly from the sales and marketing people. Some of them also knew about Luminor Hotel Pahlawan, Sidoarjo from their friends or 
relatives. The media that helped them the most to know about Luminor Hotel Pahlawan, Sidoarjo products and services are flyer and social media. However, they feel that the media is ineffective. They mention that things which is lacking from the current marketing tool are price list and pictures of the facilities. Next, 95\% of the respondents think that the idea of marketing booklet is the right solution for an informative promotion tool. To make sure the marketing booklet can deliver message to the audience, respondents were asked about the language in the marketing booklet. As the result, $80 \%$ of them think that English can be attractive but also easy to be understood.

\begin{tabular}{|c|c|c|c|}
\hline STRENGTHS & WEAKNESSES & OPPORTUNITY & THREATS \\
\hline $\begin{array}{l}\text { Luminor } \\
\text { Hotel } \\
\text { Pahlawan, } \\
\text { Sidoarjo is } \\
\text { located } \\
\text { strategically } \\
\text { in the city } \\
\text { center. } \\
\text { Luminor } \\
\text { Hotel } \\
\text { Sidoarjo is } \\
\text { considered } \\
\text { as fancy } \\
\text { business } \\
\text { hotel. }\end{array}$ & $\begin{array}{l}\text { Luminor Hotel Pahlawan, } \\
\text { Sidoarjo is more expensive } \\
\text { than other Hotels in Sidoarjo. } \\
\text { The facilities which are } \\
\text { demanded by most customers } \\
\text { such as swimming pool, gym } \\
\text { center, spa, etc. are not } \\
\text { available in Luminor Hotel } \\
\text { Sidoarjo - Pahlawan. }\end{array}$ & $\begin{array}{l}\text { High brand } \\
\text { awareness. } \\
\text { At the present, } \\
\text { Luminor Hotel } \\
\text { Sidoarjo - } \\
\text { Pahlawan's } \\
\text { main } \\
\text { competitor in } \\
\text { Sidoarjo is } \\
\text { only Fave } \\
\text { Hotel Sidoarjo. }\end{array}$ & $\begin{array}{l}\text { There are } \\
\text { several hotels } \\
\text { which are } \\
\text { built at the } \\
\text { present and } \\
\text { predicted to } \\
\text { be ready in } \\
2021 \text { and } \\
\text { become } \\
\text { Luminor } \\
\text { Hotel } \\
\text { Sidoarjo - } \\
\text { Pahlawan's } \\
\text { competitor. }\end{array}$ \\
\hline
\end{tabular}

\section{Result of USP}

Based on the SWOT analysis above, there were 3 USP that were found in Luminor Hotel Pahlawan, Sidoarjo, as listed below: competitors.

1.Luminor Hotel Pahlawan, Sidoarjo has a better brand image compared to its

- Compared to other hotels in Sidoarjo, Luminor Hotel Pahlawan, Sidoarjo has more modern ambience and higher service quality.

2.Luminor Hotel Pahlawan, Sidoarjo is located strategically in Sidoarjo.

-Compared to other hotels in Sidoarjo, Luminor is located more strategical because it is near high-way, mall, and GOR

3.Luminor Hotel Pahlawan, Sidoarjo has an outstanding restaurant.

-Wajik Resto and Café is admired by most of the customers because it is very comfortable and has buffet package. 
Kusumaningtyas: Promoting Luminor Hotel Pahlawan, Sidoarjo to Its Target Market Using a Marketing Booklet

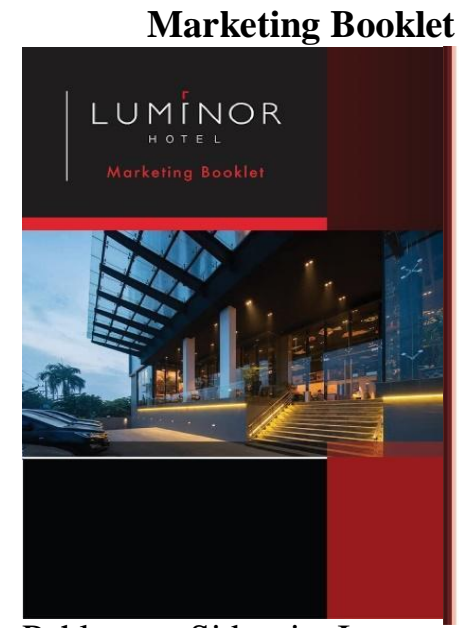

Pahlawan, Sidoarjo. It

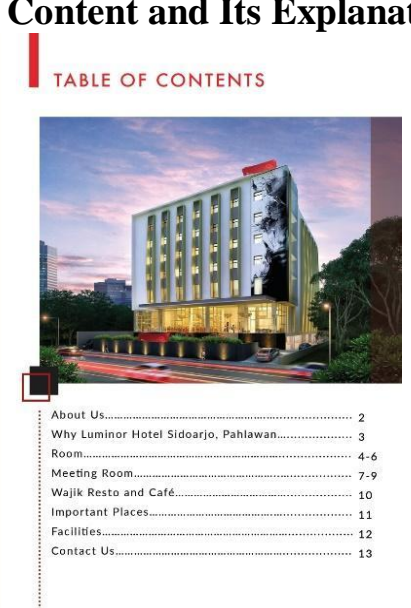

The front cover of the booklet consists of the title of the booklet which is "Luminor Hotel Sidoarjo Pahlawan, Marketing Booklet". I used "Marketing Booklet" as this booklet has all important information regarding the products and services which will be used by the marketing people to promote the hotel. I put the Luminor logo on the cover as the form of branding. Next, I also use the picture of the front view of Luminor Hotel gives impression to the audience that by opening this booklet they are going to see what inside Luminor Hotel Pahlawan, Sidoarjo looks like.

The first page inside the marketing booklet is "Table of Content". Based on the theory from Honor (2015) that I have mentioned in chapter 2, it is important to put table of contents if there are part of information that has more than one page. It will help the audience, here the customers, in finding the information needed easier. The customers do not have to flip a lot of pages for it. Therefore, I put "Table of Contents" in the very beginning of the booklet.

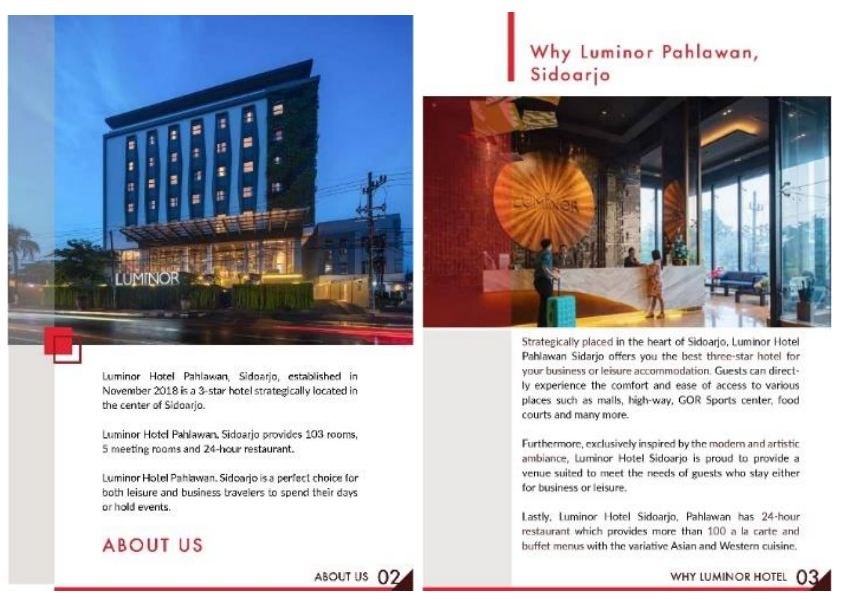

Page 2 and 3 are basically the company overview. As the theory I mentioned in chapter 2 according to honor (2012), a marketing booklet should have a company overview. This part 'About us' describes what Luminor Hotel Sidoarjo - Pahlawan is and the part 'Why Luminor Hotel Pahlawan, Sidoarjo' explains why customers should choose this hotel. In other words, here I explain a brief description of Luminor Hotel Pahlawan, Sidoarjo, then continued by its unique selling points. In the product description I write about when Luminor Hotel Pahlawan, Sidoarjo was established and what products and services that they offer. Here, I mention the room, meeting room and Wajik Resto and Café. For the unique selling point, I put 2 USPs based on the result of the customers' survey. Those USPs are strategic location and high-quality service with modern ambience. 


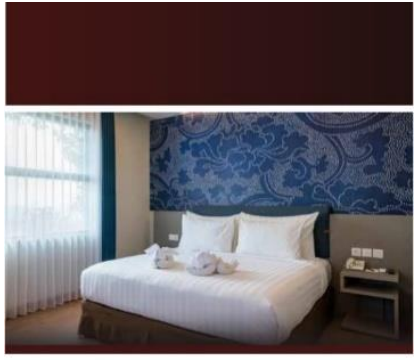

ГDeluXe ROOM

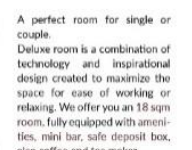

TYPES OF ROOMS O4
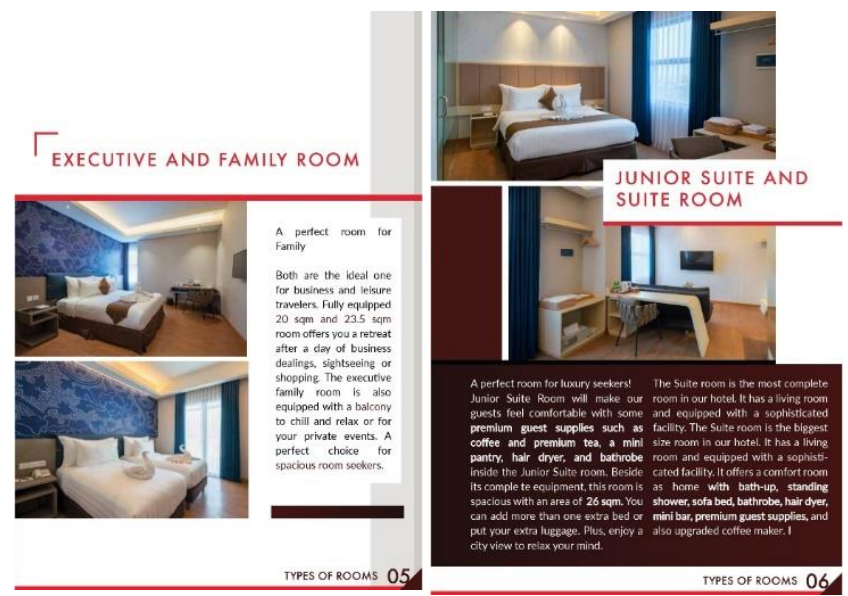

The first product to be presented in the booklet is the room. According to the theory of Honor (2015), a marketing booklet supposed to be organized. So, I put the room's part first because it is the main products of the company. On page 4 until 5, customer can find the visualization of the room with high-quality pictures. Those pages also contain the types of rooms, the total room, size room, type of beds, facilities and benefits. In addition, since most customers wonder what is the different of each type of the room, this part also mentions the description of each room which differentiate each room.
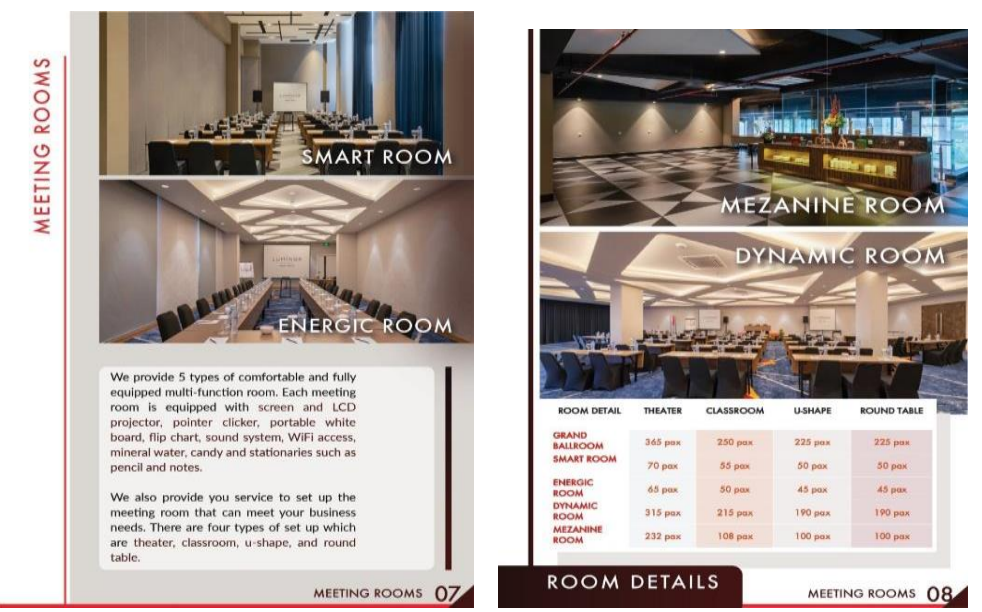

Next, on page 7 until 10 , readers can find the next product that Luminor Hotel offers which is meeting room. This part contains a brief explanation, total meeting room, meeting room size, and the capacity of each meeting room based on the setup setting. Since most customers mentioned in the survey that they would like to know about the price list, here I also add

the price list of the meeting packa

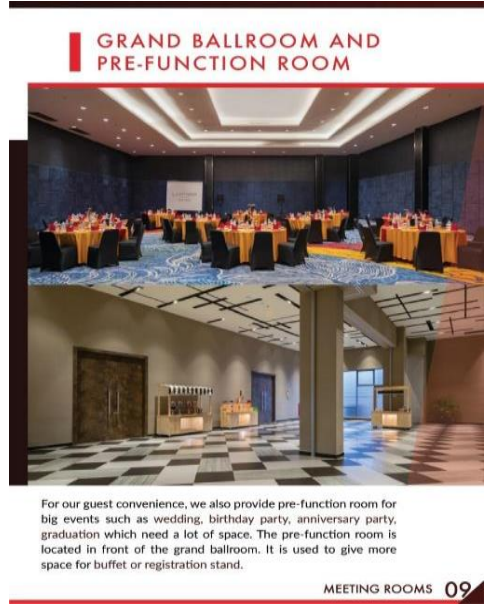

MEETING PACKAGES

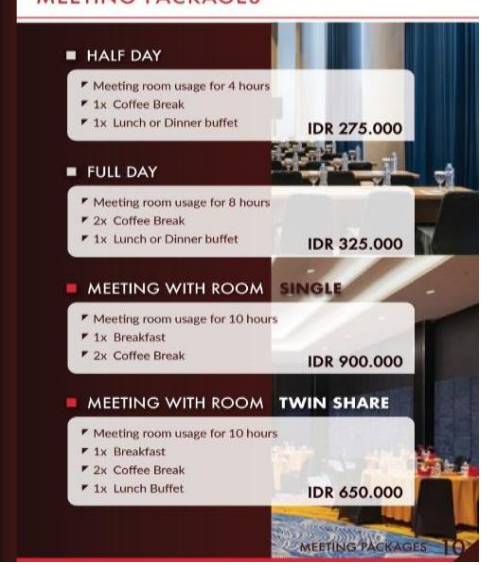

customers to know that

Luminor Hotel Pahlawan,

Sidoarjo does not rent the meeting room. It sells the meeting package and provides the meeting room in accordance with the amount pax of the package. Since the purpose of marketing booklet is to be an informative tool for the customer, here the pictures of the meeting room also give visualization to the customers about the kinds of meeting room set-up. 
Kusumaningtyas: Promoting Luminor Hotel Pahlawan, Sidoarjo to Its Target Market Using a Marketing Booklet
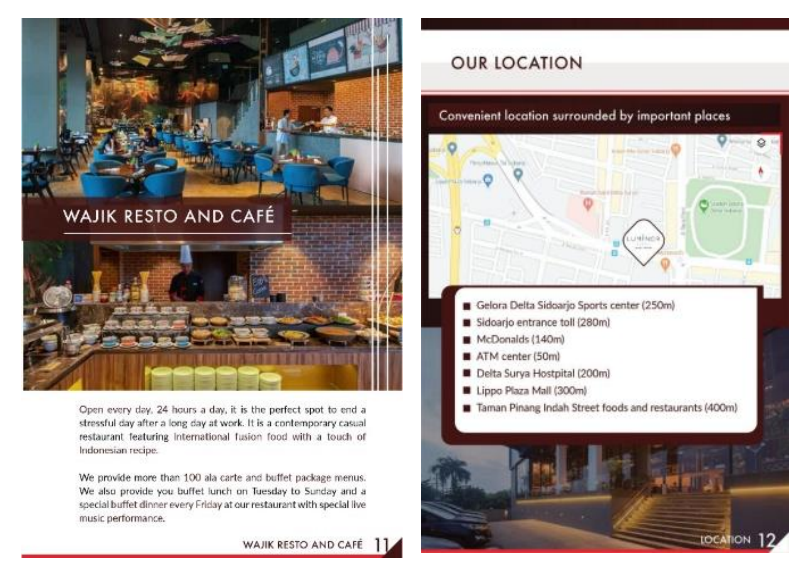

Last product to be described is Wajik Resto \& Café. In the booklet I mention the USP of Wajik Resto and Café based on customers point of view. I describe that Wajik Resto and Café is 24hour restaurant with more than 100 a la carte and buffet menus which are not available in other hotels such as FaveHotel Sidoarjo and Sun Hotel Sidoarjo. The pictures also give visualization for the audience that Wajik Resto and Café is very comfortable, spacious, and suitable for social gathering.

The fifth component is important places. Since Luminor Hotel Pahlawan, Sidoarjo is located in a strategic area. It is very important to highlight the important places around Luminor Hotel Sidoarjo - Pahlawan. The important places are gotten based on the satisfaction customers questionnaire in order to get the USP. The important places which are near Luminor Hotel Sidoarjo - Pahlawan are high-way, GOR, Lippo Mall, banks, food courts, and many more. Here, the map will support the unique selling point of Luminor Hotel Pahlawan, Sidoarjo. The map shows the specific location of Luminor Hotel Sidoarjo - Pahlawan that makes customers understand the location and why it is strategic.

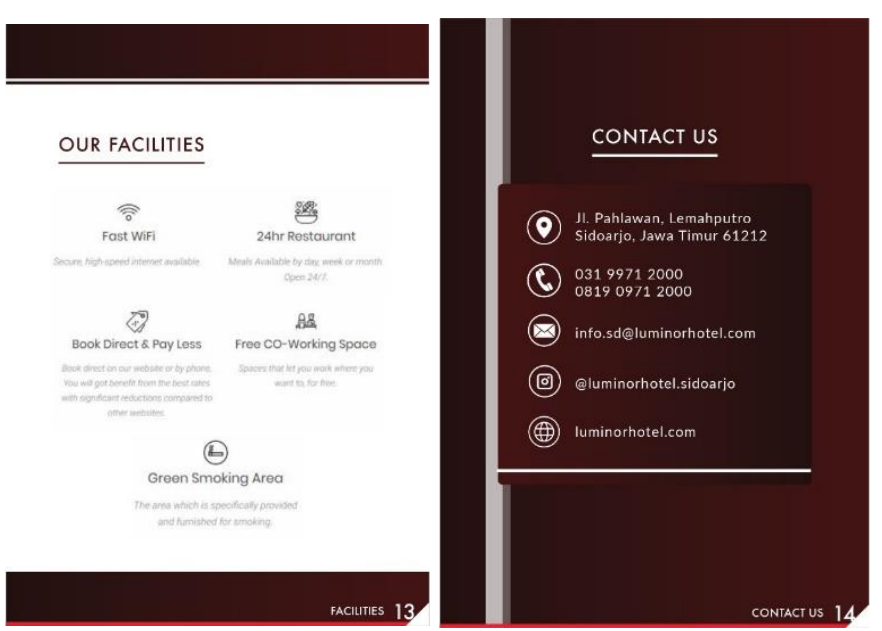

On page 13 , the marketing booklet gives information about the facilities that the Hotel provides for the guests. Since Luminor is quiet expensive compare to its competitor (Fave Hotel and Sun Hotel), it is important to also highlight the convenience that the customers get while staying at Luminor Hotel Pahlawan, Sidoarjo.

The last part of the booklet is I put some information about the hotel. First, I put the address of the hotel to help those customers who come from outside Sidoarjo to find out where Luminor Hotel Pahlawan, Sidoarjo is located. Next, I put the phone number, both the telephone number and the Whatsapp number of the hotel. It gives discretion for the customers who wants to order whether they would like to contact the hotel via Whatsapp or phone. Third, I put email address for those customers who usually have special request and needed to send it formally to the hotel. Last, I put the instagram and website of Luminor Hotel Pahlawan, Sidoarjo as the audience may need more references about the hotel.

\section{CONCLUSION}

For the Creative Thesis Project, I decided to make a marketing booklet for Luminor Hotel Pahlawan, Sidoarjo. I came up with a marketing booklet because the current promotion tool which is flyer is not effective to gain prospects attention. Customers tended to ask for more 
detail information about the room and meeting room including the pictures. Moreover, flyer which was shared to the prospects when doing telemarketing is not appealing at all. Customers frequently ask about further information but ended not interested because the sales people do not have the tool to show them about Luminor Hotel Pahlawan, Sidoarjo in attractive way. The usage of marketing booklet for is for supporting their explanation to customers about the products and services that hotel offers. Besides, marketing booklet has more complete information that includes some pictures, detail information, map, and contact information. Thus, customers will have better understandings and clear image about Luminor Hotel, Sidoarjo, Pahlawan. Moreover, the benefit of having marketing booklet can also be used for other departments in Luminor Hotel Pahlawan, Sidoarjo such as front office, food \& beverage, and accounting who usually send their staff to be a representative in exhibition. Throughout this booklet, they can learn the product knowledge.

\section{REFERENCES}

Advantages of using booklets for business marketing in Rivonia. (2016, July 12). Retrieved from https://www.minutemanpress.co.za/news/advantages-of-using-booklets-forbusiness-marketing-in-rivonia/

Bonnici, T. S. (2015). Brand and branding. Wiley encyclopedia of management. Retrieved from https://www.academia.edu/39884936/Brand_and_Branding.

Booklet. (2019). Oxfordlearnerdictionaries.com. Retrieved from https://www.oxfordlearnersdictionaries.com/definition/english/booklet?q=boo klet

Craig. (2018). 5 Benefits of Using Booklets and Brochures for Your Marketing. Retrieved from https://www.instantprint.co.uk/printspiration/marketing-with-print/5-benefits-of-usingbooklets-and-brochures-for-your-marketing.

Edmonds, S. (2019). 5 ideas for creative marketing with booklets. Retrieved from https://roundhouse.cc/us/5-ways-to-use-creative-marketing-with-booklets

Gough, O. (2017, August 22). The importance of creating a USP in today's global market. Retrieved from https://www.growthbusiness.co.uk/importance-usp- global-market2551905/

Hackley, C. (2010). Advertising and promotions: an integrated marketing communications approach. London: Sage publications Ltd.

Honor, T. (2015, March 7). Tips for better sales booklets. Retrieved from www.business2 community.com/marketing/tips-for-better-sales-booklets- 0274390

Holmes. (1990). Sociolinguistics. Amsterdam: John Benjamins publishing.

L. Reid, S. (2011, April 20). 5 Steps to determine your unique selling point. Retrieved from https://www.americanexpress.com/en-us/business/trends-and-insights/articles/5-stepsto-

Ladd, A. D. (2010). Developing effective marketing materials: brochure design considerations. The University of Tennessee. Center for Profitable Agriculture.

Lautianinen, T. (2015). Factors affecting consumers' buying decision in the selection of a coffee brand. Undergraduate Thesis. Saimaa University of Applied Sciences. Retrieved from https://core.ac.uk/download/pdf/38124382.pdf

Lidwina, A. (2020). Kelompok penduduk Indonesia terbesar dilihat dari tingkat pengeluarannya. Retrieved from

https://databoks.katadata.co.id/datapublish/2020/02/04/masyarakat- menuju-kelas-

menengah-kelompok-terbesar-penduduk-indonesia.

Marketing. (2019). Oxfordlearnerdictionaries.com. Retrieved from https://www.oxfordlearnersdictionaries.com/definition/english/marketing?q= Marketing

Medlik, S. (2011). The business of hotels $4^{\text {th }}$ edition. New York: Routledge 
Kusumaningtyas: Promoting Luminor Hotel Pahlawan, Sidoarjo to Its Target Market Using a Marketing Booklet

Putnam, J. (2019). Unique selling point. Retrieved fromhttps://neilpatel.com/blog/uniqueselling-proposition/

Rogoll, C. (2015). Star Brands: A Brand Manager's Guide to Build, Manage and Market Brands. New York: Allworth Press.

Sorrentino, M. (2014). Creative advertising: an introduction. London: Laurence king publishing Ltd.

Stone, T. L., Adams, S. \& Morioka, N. (2008). Color design Worldbook. Massachusets:

Rockport publisher.inc.

Taylor, D. (2001). Hospitality sales and promotions. United Kingdom: Elsevier Science Ltd.

Titley, B (2015). Complete Business Studies for Cambridge IGCSE \& O Level. United Kingdom: Oxford University.

Walker, J. R. (2013). Introduction to Hospitality. United States of America: Pearson.

Weitz, B. A., \& Wensley, R. (2002). Handbook of Marketing. Thousand Oaks, CA: SAGE.

Yeshin, T. (2006). Sales Promotion. London: Thomson Learning 